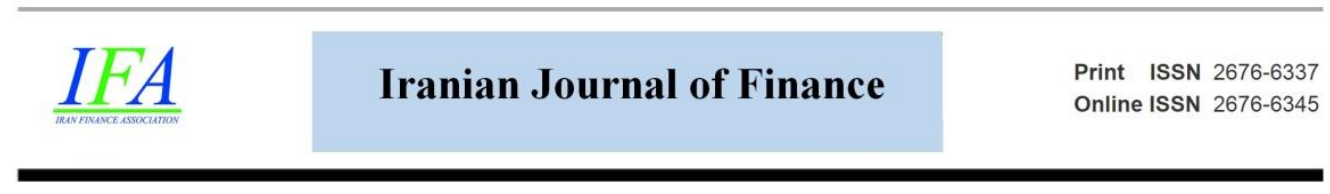

\title{
The Relationship between Foreign Direct Investment Inflows of World, Foreign Direct Investment Inflows of Turkey and Types of the Special Economic Zone: Evidence from 1980-2019
}

\section{Demet Ozocakli*}

*Corresponding Author, Assistant Prof, Department of Foreign Trade, Gaziantep University, Gaziantep, Turkey. (Email: dozocakli@gantep.edu.tr)

\section{Bahman Khanalizadeh}

$\mathrm{PhD}$ Candidate in Financial Economics, Department of Economics, Islamic Azad University, Zanjan Branch, Zanjan, Iran. (Email: Khanali.bahman@yahoo.com)

Document Type: Original Article

Received: 2021/06/21

Accepted: 2021/11/03
2022, Vol. 6, No. 2. 1-27.

Published: 2022/02/18

\begin{abstract}
There are many factors affecting Foreign Direct Investment inflows into the countries. One of them is Special Economic Zones that encourage Foreign Direct Investment inflows and achieve remarkable results in the world. Special Economic Zones are defined in the United Nations Conference on Trade and Development as the regions where production, trade and storage are not limited to time and are exempt from customs and taxes. This study analyzed the relationship between the Foreign Direct Investment inflows of Turkey, the Foreign Direct Investment inflows of the World and the number of the Special Economic Zone types analyzed using the Autoregressive Distributed Lag Method from 1980 to 2019. The results show that Foreign Direct Investment inflows of the World have a positive and significant effect on Foreign Direct Investment inflows Turkey in the long term and the short term. Also, the number of total Special Economic Zone has a positive and significant on the
\end{abstract}


Foreign Direct Investment inflows of Turkey. Foreign Direct Investment inflows of Turkey increase $1.01 \%$ and $2.58 \%$ in long term and short term, respectively when the increase is $1 \%$ in the number of total Special Economic Zone. Moreover in this study, a number of the Special Economic Zone types such as OIZ, TDZ, FZ have been analyzed.

JEL Classifications: B27, F02, F13

Keywords: Type of the special economic zones, Organized Industrial Zone, Technology Development Zone, Free Zone, Foreign Direct Investment Inflows, ARDL Method

DOI: https://doi.org/ 10.30699/IJF.2021.291522.1247 Publisher: Iran Finance Association

Type of License: Creative Commons License (CC-BY 4.0)

\section{Introduction}

The United Nations stated that it has an important role for Foreign Direct Investment (FDI) in financing development and advancing towards sustainable development goals (UNCTAD, 2015: 213). Asiedu (2002) stated that countries need FDI flows to support domestic savings and that FDI flow not only provides the necessary capital for investment but also encourage growth and development by bringing employment, management skills and technology. The FDI contributes to the improvement of the workforce quality of the invested country, the increase of its welfare, and the more stable operation of its financial markets. At the same time, countries that can attract FDI are less affected by global economic fluctuations by reaching a wider pool of investors (Presidency of the Republic of Turkey Investment Office, 2020: 26).

While there was a small level of FDI inflows in Turkey in the 1973-2002 periods, there was a larger increase in FDI inflows in the 2002-2020 period. In parallel with FDI inflows, there has been a significant increase in the number of companies with foreign capital. Especially since the early 2000s, a net FDI inflow of approximately $\$ 209$ billion has been realized in Turkey (Presidency of the Republic of Turkey Investment Office, 2021b).

Considering the share of FDI inflows in the GDP, a slow increase was observed in the world towards the end of the 1980s, while a slow increase was observed in Turkey parallel to the world. In addition, while a great increase was observed in the world, especially towards the 2000s, a great increase was observed in Turkey in 2001 in parallel with the increase in the world. In 
general, it is observed that Turkey moves in parallel with the world in terms of the share of FDI inflows in GDP. Among the reasons for the increasing trend in FDI inflows to Turkey in the last twenty years, the reforms and incentives implemented since the 2000s have played an important role, apart from the fact that there is a trend parallel to the world. In addition, the number of Special Economic Zones (SEZ) has increased rapidly in Turkey since the 1980s. SEZs are defined as regions with a limited geographic area, tax exemptions, flexible and private investment policies and practices in which procedures are simplified.SEZs are defined in the United Nations Conference on Trade and Development (UNCTAD) as the regions where production, trade and storage are not limited to time and are exempt from customs and taxes (FIAS, 10 2008). There are SEZs around the world that encourage FDI inflows and achieve remarkable results. Most SEZ established in the Asian Tigers in the 1970s and 1980s facilitated economic development by causing FDI inflows. Cumulative FDI inflows created by SEZs in China accounted for eighty percent of the total FDI inflows in the country, and SEZs have been found to have increased FDI inflows over the years. FDI, which inflowed the Ecozone region in the Philippines, was thirty percent in 1997 and reached 80 percent in 2000 (FIAS, 2008: 35). Inflowing the Export Processing Zones in Bangladesh, FDI reached $\$ 52$ million in the period 1994-1999 and about $\$ 1.5$ billion in 2009 (Farole and Akinci, 2011: 29). The share of FDI inflowing SEZs in the Philippines increased from thirty percent in 1997 to over 80 percent in 2000 (UNCTAD, 2020). In this context, it is aimed to determine the relationship between the increase in the number of types of SEZ and FDI inflows of the world and FDI inflows of Turkey. For this purpose, to determine this relationship ARDL method was used by considering from 1980 to 2019. In this study firstly, the situation of FDI inflows in Turkey and the world has been discussed. Secondly, the situation of SEZ in the world and Turkey has been examined. Thirdly, information has been given again used method in the methodology section. Fourthly, the findings obtained according to the analysis results are discussed in the result and conclusion.

\section{Foreign Direct Investment (FDI)}

The United Nations has stated that It has an important role for FDI in financing development and moving towards sustainable development goals (UNCTAD,2015:213). Asiedu (2002) said countries needed FDI flow to support domestic savings. According to him, FDI flow provides the capital needed for investment, as well as bringing employment, management skills and technology, encouraging growth and development. FDI contributes to improving the quality of the workforce of the invested country, improving its 
prosperity and making its financial markets work more steadily. At the same time, countries with attracted FDI capacity are less affected by global economic fluctuations by reaching a wider pool of investors (Presidency of the Republic of Turkey Investment Office,2020:26).

The first step regarding foreign direct capital investments in Turkey was made with the "Foreign Capital Incentive Act" dated January 18, 1954, and numbered 6224. With this law, the desired level of foreign capital flow has not been achieved. After the liberalization of the foreign exchange regime in the 1980s, improvements to the foreign capital law, privatization policy and regulations aimed at reducing bureaucracy, FDI in Turkey began to occur at more meaningful levels. In the early 2000s, Turkey entered the process of structural transformation. With this transformation process, there have been large increases in FDI inflows (Presidency of the Republic of Turkey Investment Office, 2021a:13). Table 1. reforms to investments in Turkey are given chronologically.

Table 1. Reforms for Investments

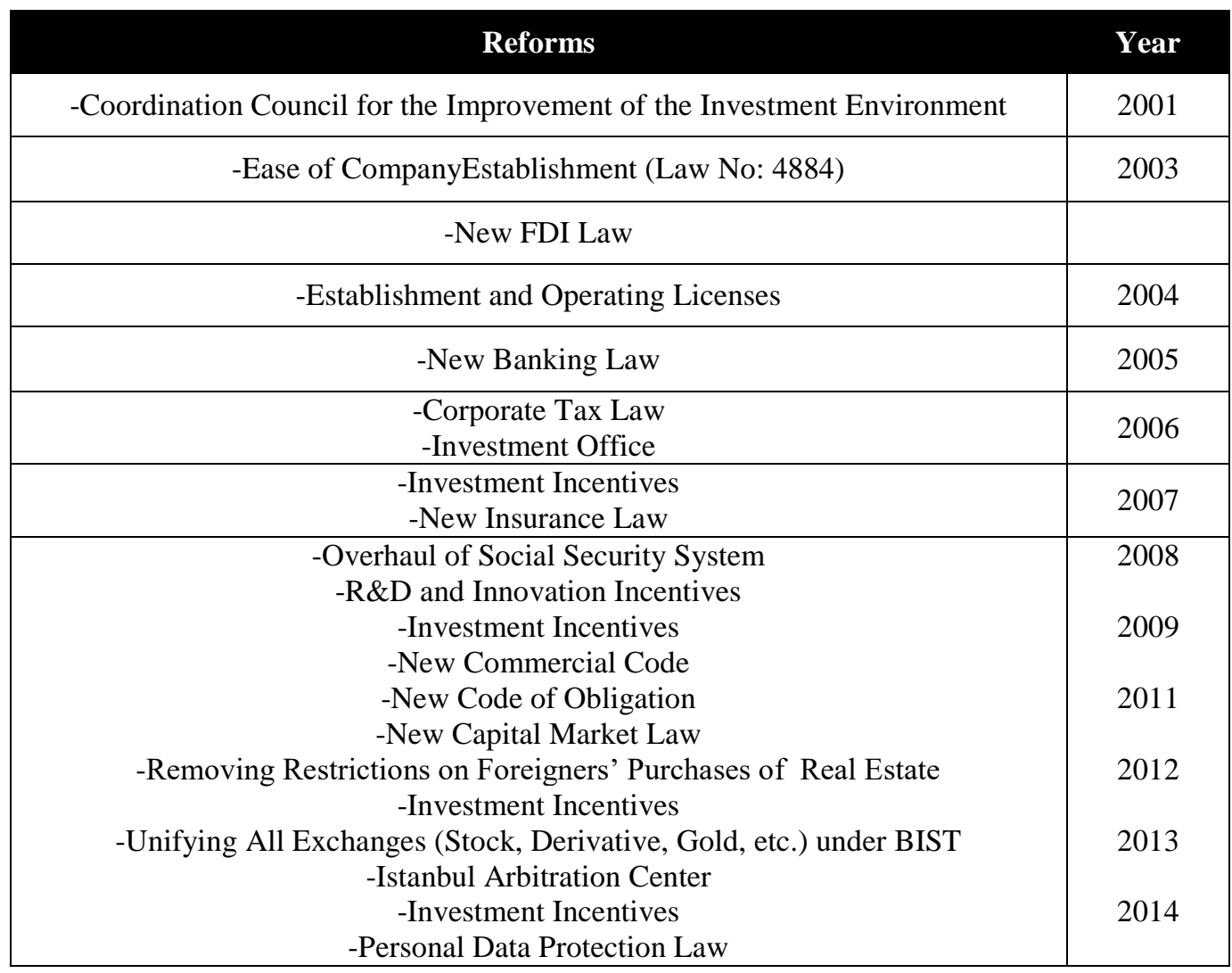


The Relationship between Foreign Direct Investment ...

\begin{tabular}{|c|c|}
\hline $\begin{array}{c}\text {-Industrial Property Law (IPR) } \\
\text {-Production Reform Package } \\
\text {-New Labor Courts Code }\end{array}$ & 2016 \\
-Amendments to Improve Doing Business (Law 7099) \\
-Ease of Doing Business Reform Package \\
-Tech-Driven Industry Initiative
\end{tabular}

Source: Presidency of the Republic of Turkey Investment Office

The new FDI law, introduced in 2003, is seen as an important step for the FDI. The purpose of the new FDI law is stated as "Promoting foreign direct investments, protecting the rights of foreign investors and complying with international standards in investment and investor definitions, converting the permit and approval system for the realization of foreign direct investments into an information system and increasing foreign direct investments through the identified policies". According to FDI law "Unless otherwise stipulated by international agreements and special law provisions, foreign investors are free to make foreign direct investments in Turkey, foreign investors are subject to equal treatment with domestic investors, and net profits, dividends, sales, liquidation and compensation fees arising from the activities and transactions of foreign investors in Turkey, amounts to be paid in exchange for licenses, management and similar agreements, and foreign loan principal and interest payments can be transferred freely abroad through banks or private financial institutions and foreign personnel to be employed in companies, branches and organizations established within the scope of this law will be allowed to work by the Ministry of Labor and Social Security" (Foreign Direct Investment Law, 2003).

In addition to all these reforms, bilateral investment protection treaties with 82 countries, treaties to avoid double taxation with 86 countries were performed. Furthermore, the incentives offered are tax deduction and exemption within the scope of manufacturing incentives, tax deduction and training support within the scope of employment incentives, tax deduction and exemption within the scope of $R \& D$ and innovation incentives, tax deduction for exporting services (engineering, architecture, design, software, medical reporting, accounting, call center, data center, education and healthcare), support R\&D and tax deduction and exemption within the scope of technology development zone, tax deduction and exemption in a free zone and developed infrastructure in organized industrial zones (Presidency of theRepublic of TurkeyInvestment Office,2021a:15-16). 
It is shown in Figure 1 that net FDI inflows increase by the year. While there were low FDI inflows in Turkey in the 1973-2002 period, there was a great increase in FDI inflows in the 2002-2020 period. It is thought that reforms made for investments, development and increase in investment environments, incentives provided for investment environments are the reasons for the increase in FDI (within the scope of technology development zone to support R\&D and tax deduction and exemption, within the scope of exclusive zones tax deduction and exemption in a free zone and developed infrastructure in organized industrial zones).

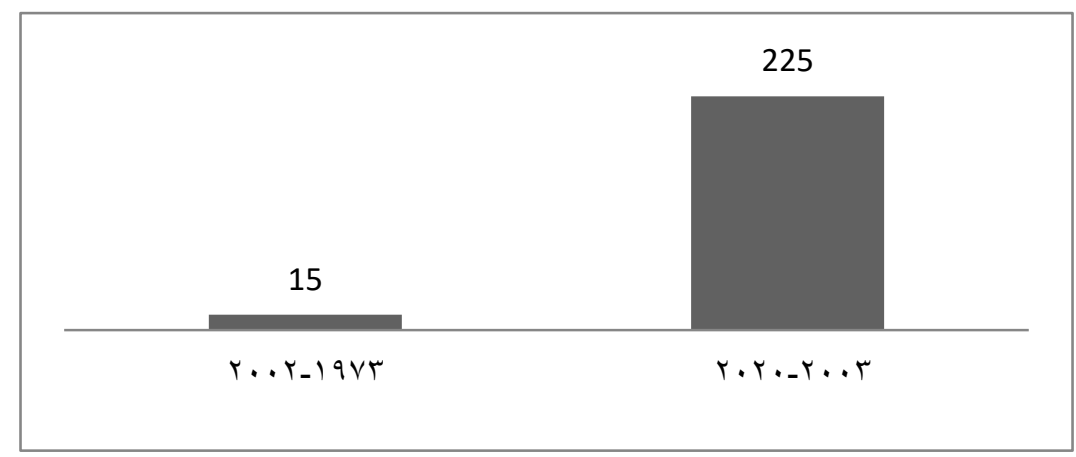

Figure 1. FDI Inflows (US \$ billions)

\section{Source: CBRT}

In parallel with FDI inflows, a significant increase is observed in the number of companies with foreign capital. The numbers of companies with foreign capital are given in Figure 2. Reforms and liberalization efforts in Turkey have led to a net FDI inflow of approximately $\$ 209$ billion since the early 2000s (Presidency of the Republic of Turkey Investment Office, 2021b).

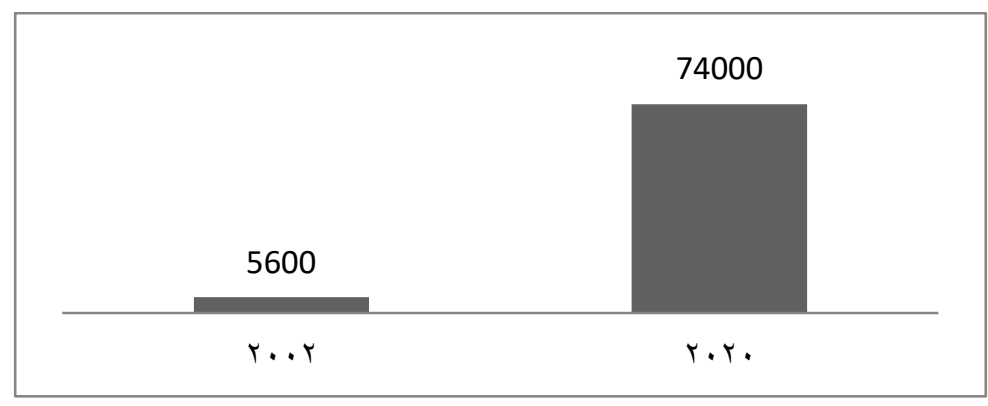

Figure 2. Number of Companies with Foreign Capital

Source: Ministry of IndustryandTechnology 
In Figure 3 The number of companies with foreign capital and FDI inflows (million US \$) for the period 2002-2019 is given together. It is seen that these two are in the same parallel. In 2004, there was a significant increase in net FDI inflows and the number of foreign capital companies. The reason for this increase is thought to be the reforms made in the 2000s, the increase in the number of investment regions, the incentives provided for investment environments and the increase in FDI inflows in the world. The 2008 global economic crisis adversely affected the investment climate. Therefore, the increase experienced in 2004 was replaced by a decrease. In 2011, there was an increase in FDI inflows and the number of companies with foreign capital. However, due to the negative investment climate in the world, FDI inflows decreased again. It would be correct to attribute the increase experienced in 2015 and the decrease experienced immediately after it to the negative investment climate in the world.

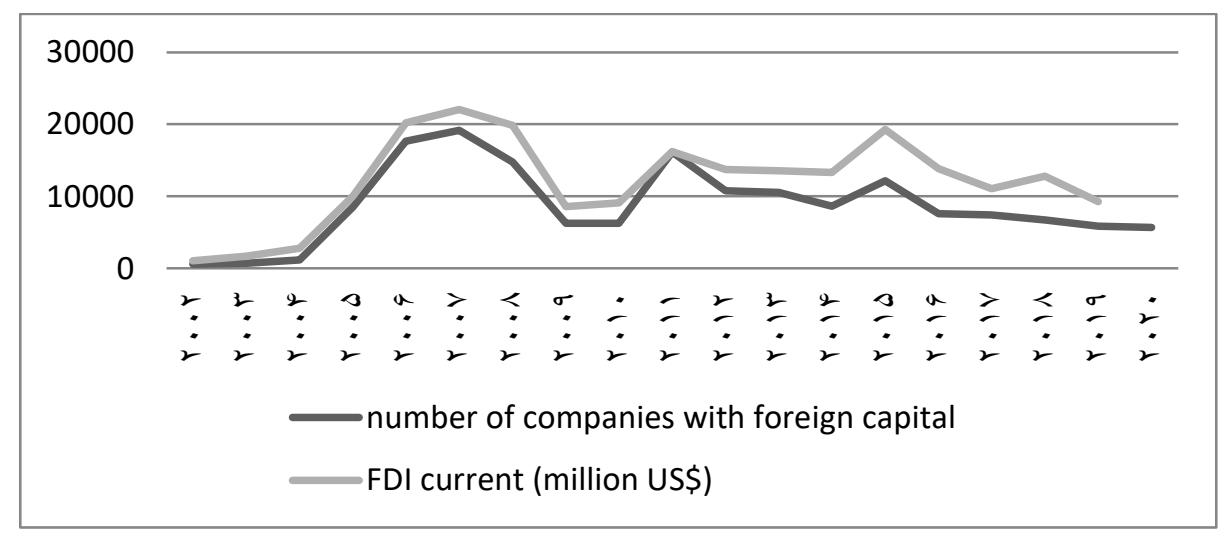

Figure 3. Number of Companies with Foreign Capital and FDI inflows current (million US\$)

Source: Ministry of Industry and Technology, International Direct Investment Statistics, Number of Companies with Foreign Capital Companies Operating in Turkey, The World Bank, FDI current million US\$

In Figure 4. FDI inflows (\% GDP) is shown. A slow increase in FDI inflows around the world towards the end of the 1980s draws attention. FDI inflows in Turkey have increased in parallel with the world. There is a great increase in FDI inflows in the world towards the 2000s. Turkey experienced an increase in FDI inflows in 2001 in line with the increasing trend in the world, but this increase resulted in the same decrease again. The reason for this decrease is thought to be the financial crisis experienced in Turkey in 2001. Then, in 2003, parallel to the world, there was a great increase in FDI inflows in Turkey. The reforms made in Turkey and the new FDI law are thought to be 
effective in this increase. The global economic crisis in 2008 affected the whole world and negatively affected the investment climate. Due to this negative investment climate, there was a sharp decrease in FDI inflows.

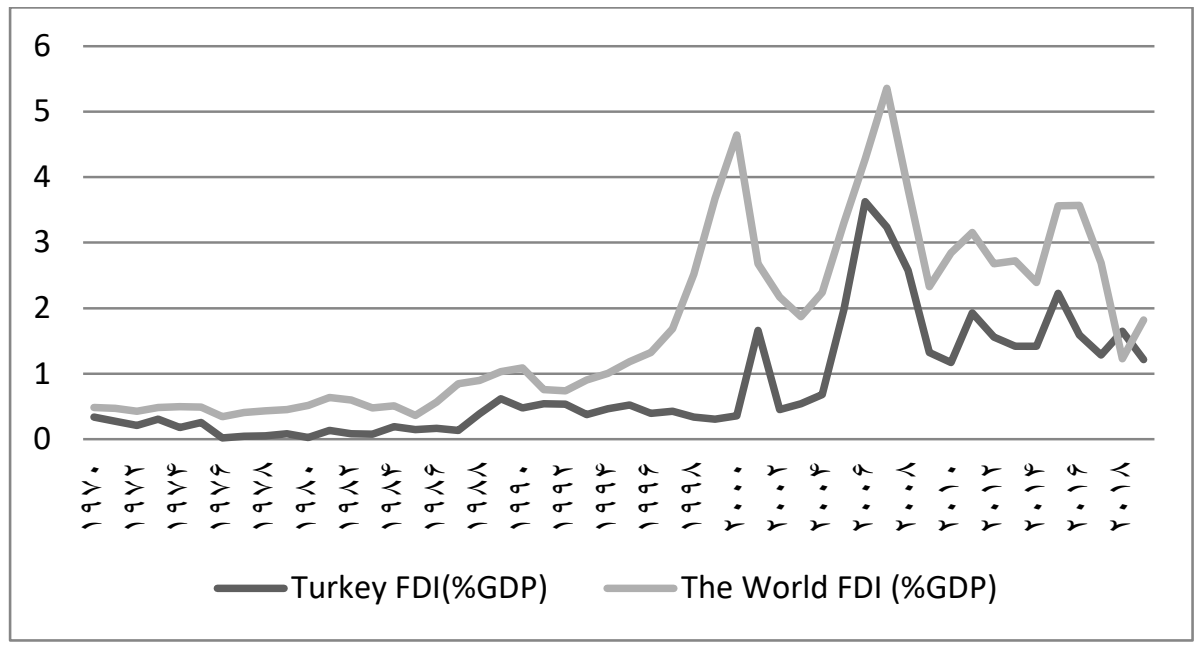

Figure 4. Net F.D.I. inflows (\%GDP)

Source: The World Bank

With globalization, facts such as the lack of trust in countries, trade wars, Brexit process, and geopolitical tensions caused fluctuations in international direct investments, which are seen as indicators of the world economic situation, in the post-crisis period. (Presidency of the Republic of Turkey Investment Office, 2021a: 31).

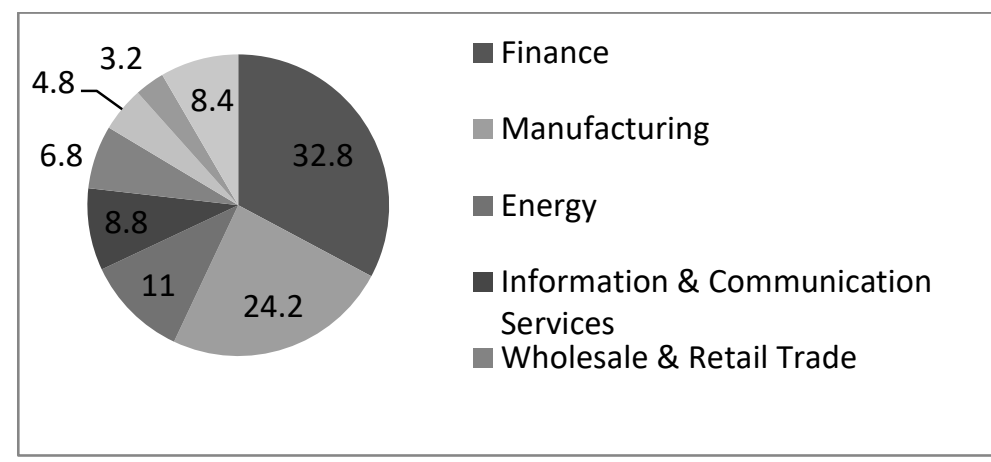

Figure 5. The Sectoral Distribution of FDI Inflows in Turkey

Source: Presidency of the Republic of Turkey Investment Office 
Figure 5 shows the sectoral distribution of FDI inflows in Turkey. It seems that the most attractive sectors are finance, manufacturing, energy, information and communication technologies, wholesale and retail trade, construction. The shares of the sectors with the highest FDI inflows are ranked as $33 \%$ in finance, $24 \%$ in the manufacturing industry, $11 \%$ in energy, and $9 \%$ in ICT (Presidency of the Republic of Turkey Investment Office, 2021a: 21).

\section{Special Economic Zones (SEZs)}

Different definitions are made in the literature for SEZs, which are applied as a policy tool for economic development and cover approximately thirty percent of world trade (UNDP, 2015). SEZs are defined as regions with a limited geographic area, tax exemptions, flexible and private investment policies and practices in which procedures are simplified. SEZs were defined in the United Nations Conference on Trade and Development (UNCTAD) as the regions where production, trade and storage are not limited to time and are exempt from customs and taxes (FIAS, 10 2008). Fang (1994) defined SEZs as economic areas that allow foreign investors to enter the region and flow modern technology and management experiences into the region. Dobrogonov and Farole (2012) defined geographically restricted areas operating with administrative, financial and regulatory regimes, unlike the part of countries outside the region, and stated that different investment conditions and taxation regulations were applied in these regions. Wang (2009), on the other hand, expressed SEZs as segregated regions, which are used to encourage industry, export and manufacturing, and contain more liberal laws and policies than the country's general economic laws. Pakdeenurit and Suthikarnnarunai (2014) defined areas that were established specifically to attract foreign investors to the country and include special investment policies such as tax deduction, work permits for foreign workers, and financial support. Çakmak et al. (2017) defined geographically restricted areas operating with administrative, financial and regulatory regimes that differ from other parts of countries. He expressed that these regions, which have a large geographical area and industrial infrastructure, also include sub-regions such as ports, airports, universities and vocational schools, residential areas, touristic and commercial areas. Akinci and Crittle (2008) stated that SEZs cover types of regions such as Free Trade Zones, Free Production Zones, Investment Zones, Free Ports, Single Factory and Specialized Zones. Çağlar and Kurtsal (2011) included Export Processing Centers, Free Zones, Free Ports, Investment Zones, Industrial Zones, Science and Technology Zones, Innovation Zones, Organized Industrial Zones, Small Industrial Sites and Technology Development Zones within the scope of SEZs. 
According to the Neoclassical Trade Theory, SEZs are defined as residential areas that offer free trade policies to promote trade. As it is known, the Neoclassical theory expresses free trade as the first policy. According to neoclassical theory, when free trade is not politically viable, SEZs are seen as the second-best policy tool that helps to gain some welfare gains. According to this theory, SEZs are statically viewed as trade distortions for reasons such as promoting unfair competition, lowering governments' income, and remaining production settlements with a small contribution to the economy if the rest of the economy is not liberal. On the other hand, it has been stated that SEZ structuring can be useful when used as a reform tool to improve economic reforms (Madani, 1999). According to political economy, SEZs is based on public choice theory (Buchanan \& Tullock, 1962). Accordingly, it was stated that government intervention encouraged lobbying, the best strategy in all countries and situations was the strategy in which the minimalist government approach based on the liberal system was adopted, and that free trade with the least intervention could provide economic growth. According to the political economy, it has been stated that the purpose of SEZ policies is to create income for many capitalists and reduce overall welfare by facilitating the land acquisition and offering tax incentives at the expense of the rest of the population. According to the Heterodox School, it has been argued that developmental governments play an important role in subjects such as investment, human capital, technology acquisition, institutionalization, and the promotion of institutional reforms and policies (Chang, 2002). Heterodox School stated that domestic companies do not have technical, marketing and managerial knowledge, rarely have access to international distribution channels, and SEZ policies can be used to fill this gap. According to the heterodox approach, it was stated that SEZ applications offer a good investment climate in terms of effective infrastructure, good governance, simple regulatory systems, accessible skilled workforce, tax incentives, finance and strategic location. In this context, with the positive investment climate created, FDIs attracted the country with better technology and management skills make important spreads on learning and doing business, provide positive effects on human capital in the host country and provide learning development and transformation through the flow of knowledge, talent and technology It is stated that it will provide contributions (Aggarwal, 2010: 14). Due to increases in SEZs around the world, trade and economic reforms in the rest of the economy have been adopted more. 


\section{SEZs of the World}

According to UNCTAD data, approximately 5400 SEZs in the world differs by country in terms of the purpose of the establishment (UNCTAD, 2019:xii).SEZs in South and Southeast Asian countries are mostly positioned in areas where the industry is not developed, aiming to eliminate regional development differences. SEZs in fast-developing countries such as China, Russia, India and South Africa was established to increase foreign trade, technology transfer and sustainability and to discriminate against thematic fields. The types of SEZ established may vary according to the level of development of the countries. Free zones that facilitate trade logistics are mostly more common in developed countries. Focused on developing innovation capability, multi-sector, acting for industrial development purposes and specializing in integrated SEZs are mostly established in developing countries (UNCTAD,2019:xiii).

Table 2. Types of Zone in the World

\begin{tabular}{|c|c|c|c|c|c|}
\hline Types of Zone & $\begin{array}{c}\text { Developmen } \\
\text { t Objective }\end{array}$ & $\begin{array}{c}\text { Physical } \\
\text { Configuration }\end{array}$ & $\begin{array}{c}\text { Typical } \\
\text { Location }\end{array}$ & $\begin{array}{c}\text { Eligible } \\
\text { Activities }\end{array}$ & Markets \\
\hline $\begin{array}{c}\text { Free Trade Zone } \\
\text { (Commercial Free } \\
\text { Zone) }\end{array}$ & $\begin{array}{l}\text { Support } \\
\text { Trade }\end{array}$ & $\begin{array}{l}\text { Size }<50 \\
\text { Hectares }\end{array}$ & Ports of Entry & $\begin{array}{c}\text { Entrepot and } \\
\text { trade-related } \\
\text { activities }\end{array}$ & $\begin{array}{l}\text { Domestic, } \\
\text { re-export }\end{array}$ \\
\hline Traditional EPZ & $\begin{array}{c}\text { Export } \\
\text { Manufacturi } \\
\text { ng }\end{array}$ & $\begin{array}{c}\text { Size }<100 \\
\text { Hectares; Total } \\
\text { area is } \\
\text { designated as an } \\
\text { EPZ } \\
\end{array}$ & None & $\begin{array}{l}\text { Manufacturing, } \\
\text { other processing }\end{array}$ & $\begin{array}{l}\text { Mostly } \\
\text { export }\end{array}$ \\
\hline Hybrid EPZ & $\begin{array}{c}\text { Export } \\
\text { Manufacturi } \\
\text { ng }\end{array}$ & $\begin{array}{c}\text { Size }<100 \\
\text { Hectares; only } \\
\text { part of the area } \\
\text { is designated as } \\
\text { an EPZ }\end{array}$ & None & $\begin{array}{l}\text { Manufacturing, } \\
\text { other processing }\end{array}$ & $\begin{array}{c}\text { Export and } \\
\text { Domestic } \\
\text { market }\end{array}$ \\
\hline Free Port & $\begin{array}{c}\text { Integrated } \\
\text { Developmen } \\
\mathrm{t}\end{array}$ & Size $>100 \mathrm{~km}^{2}$ & None & Multi-use & $\begin{array}{l}\text { Domestic, } \\
\text { internal } \\
\text { and export } \\
\text { markets }\end{array}$ \\
\hline $\begin{array}{l}\text { Enterprise Zone, } \\
\text { Empowerment, } \\
\text { Urban Free Zone }\end{array}$ & $\begin{array}{c}\text { Urban } \\
\text { Revitalizatio } \\
\mathrm{n}\end{array}$ & $\begin{array}{l}\text { Size }<50 \\
\text { Hectares }\end{array}$ & $\begin{array}{c}\text { Distressed } \\
\text { urban or rural } \\
\text { areas }\end{array}$ & Multi-use & Domestic \\
\hline $\begin{array}{c}\text { Single Factory } \\
\text { EPZ }\end{array}$ & $\begin{array}{c}\text { Export } \\
\text { Manufacturi } \\
\text { ng }\end{array}$ & $\begin{array}{l}\text { Designation for } \\
\text { Individual } \\
\text { enterprises }\end{array}$ & Countrywide & $\begin{array}{l}\text { Manufacturing, } \\
\text { other processing }\end{array}$ & $\begin{array}{l}\text { Export } \\
\text { Market }\end{array}$ \\
\hline
\end{tabular}

Source: FIAS (2008) 
SEZs around the world are listed by the World Bank according to the Arcgis data system. Accordingly, SEZs Free Trade Zone, Free Zone, Free Industry Zone, Industrial Zone, General Industrial Zone, Organized Industrial Zone, Export Processing Zone, Special Economic Zone, Industrial Complex, Ecozone, Industrial Development Zone, Industrial Area, Commercial Free Zone, Free Tax Zone, Foreign Investment Zone, Hi-Tech Park, Industrial Zone, Economic Zone, Integrated Special Zone (The World Bank). SEZ classification by FIAS is given in Table 1. Accordingly, the Free Trade Zone is expressed as duty-free zones that offer storage and distribution opportunities for trade, transfer and re-export operations.

The Export Processing Zone is defined as traditional and hybrid segregated regions, offering conveniences and special incentives for manufacturing and related activities aimed mainly at export markets. The Traditional Export Processing Zone is defined as regions created for exportoriented enterprises licensed under the entire field regime. Hybrid Export Processing Center is defined as the regions in which a general region open to all industries, regardless of export orientation, is subdivided and has a separate area reserved for export-oriented enterprises with export processing zone registered businesses. Freeports is defined as the regions that generally cover a very large area, including all kinds of activities including tourism, retail and sales, provide on-site residence permits and provide a wider set of incentives and benefits. The Institutional Region has been described as the regions, most of which are located in developed countries, aiming to revitalize distressed rural and urban areas through the provision of tax incentives and financial grants. The Single Factory Export Processing Zone is defined as the regions where incentives are provided to individual businesses regardless of location, and factories do not need to be located in a specific region to benefit from incentives and privileges.

In addition to these SEZ types, nowadays many specialized innovative zone development programs for the domestic and export market have emerged. In this direction, SEZs were established beyond trade and labor-intensive production activities focusing on industries such as advanced technology, financial services and tourism. In addition, SEZs, which focuses on environmental performance, commercialization of science, regional development and urban transformation, has also started to be established (UNCTAD, 2019: xiii). Science and Technology Parks that promote high technology, Petrochemical Zones that encourage the energy industry, Financial Services Related Regions that enable offshore development, Software and Internet Zones that enable the development of software and information 
communication (IT) services, Tourism Zones that integrate tourism development, Logistics Parks and Cargo Villages that provide logistics support and Airport-Based Zones that air cargo trade and transfer are established (FIAS, 2008: 10).

SEZs in Turkey are classified as Free Zones, Organized Industrial Zones and Technology Development Zones according to the Arcgis data system made by the World Bank. FIAS (2008) made Hybrid Export Processing Zone and Free Trade Zone classification for SEZs in Turkey (FIAS, 2008: 15). Çakmak et al. (2017), in parallel with the World Bank, classified SEZ types in Turkey as Organized Industrial Zones, Technology Development Zones and Free Zones.

Figure 6. shows the number of the Total SEZ, OIZ, FZ, TDZ in Turkey for the period 1980-2019. OIZs have steadily increased since 1980. According to the law, OIZs stated that "To ensure the structuring of the industry in areas deemed appropriate, to prevent distorted industrialization and environmental problems, to direct urbanization, to use resources rationally, to benefit from information and information technologies, to place and develop industrial types within a certain plan, within the ratios of the zoning plans of land plots whose boundaries have been approved. It is defined as the production areas of goods and services, which are planned and operated by allocating them for the industry within certain systems, equipped with necessary common areas, service and support areas and technology development zones, aiming efficiency in resource use (Organized Industrial Zones Law, 2000). FZs started to be established in the 1980s and their number increased until 2000 and then remained stable. While the establishment of FZ was not on the agenda due to the implementation of the import substitution policy regime in Turkey in the 1930-1980 period, FZs was used as a policy tool with the adoption of exportoriented development policies and the decisions of January 24, 1980.FZs was established with the Free Zones Law No. 3218 published in 1985 to encourage production and investment for foreign trade, accelerate technology inflow and increase FDIs. TDZs started to be established as of 2001. TDZs states in the law that "companies that use high/advanced technology or for new technologies produce/develop technology or software by using the facilities of a certain university or high technology institute or R\&D center or institute, and a technological invention becomes a commercial product, method or service within or near the same university, high technology institute or R\&D center or institute area, which they operate to transform and in this way contribute to the development of the region; It is defined as a site where academic, economic and social structure is integrated or a technopark with these features (Technology Development ZoneLaw, 2001). 


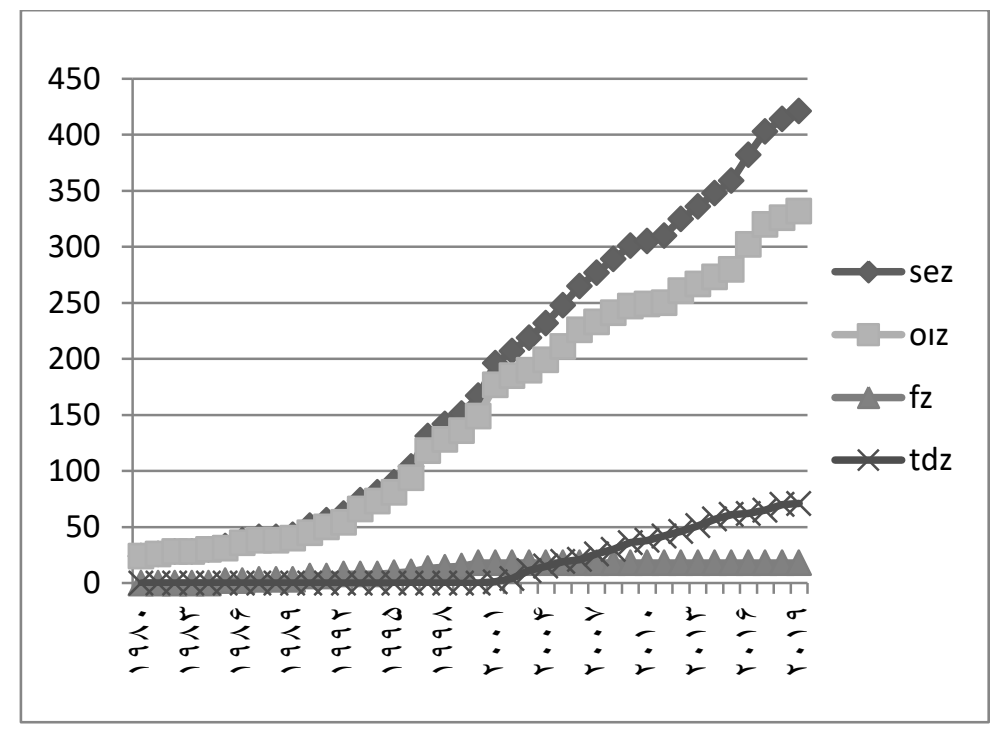

Figure 6. Number of SEZs

Source: Ministry of Industry and Technology, Ministry of Trade, Organized Industrial Zone Supervisor

In the Special Economic Zones Workshop Towards 2023, it was emphasized that a new SEZ understanding is needed to ensure the transition from medium technology to high technology. It was emphasized that in the SEZs, besides OIZs, FZs and TDZs, logistic centers should be established and integration to the global economy should be provided. For SEZs, it is described that Turkey has the potential to be a driving force (TOBB, 2011).

\section{Literature Review}

There have been several studies in the literature addressing the effect of SEZs on FDI inflows. Kaur and Singh (2020) discussed the employment creation and investment attracting potential for SEZs in the Indian economy for the period 2006-2018. According to the analysis results of 223 SEZs in this period, SEZs played an important key role in terms of employment creation and attracting FDI. Tien et al. (2020) explored the importance of infrastructure and business environment, addressing the role of SEZ organization in attracting FDI for Vietnam. It was determined that the causal relationship between the provincial FDI attracting and regional policies in the country was positive between 2011 and 2015. Wang (2013) compared the early and later periods of the regions with SEZ in China and found that the SEZ program caused FDI increases only through the displacement of companies. It was stated that municipalities with more than one SEZ structure create greater impacts than municipalities with 
only one SEZ structure. According to the analysis results, it was found that SEZs caused an increase in FDI in China. Chang (2007) stated that the adoption of the SEZ model in China under highly specific criteria provides a platform for attracting FDI, which not only supports the development of export-oriented sectors in China, but also the development of comprehensive economic reforms. The SEZs in China were analyzed by Liu and Peng (2020) using the time-varying difference specification method. It has been determined that SEZs cause an increase in FDI inflows. Dorożyński et al. (2016) found that there is a statistically positive and significant relationship between SEZs and FDI inflows in Poland. No study in the literature empirically examines the relationship between SEZ and FDI for Turkey. To fill this gap, it is analyzed the relationship between FDI inflows of the World and FDI inflows of Turkey and the type of the SEZ was analyzed using the ARDL test from 1980 to 2019 in this study.

\section{Data and Models}

\section{Data}

This study uses annual time series data from 1980 to 2019 for Turkey, Foreign Direct Investment Inflows of Turkey (FDIT) (Current US\$), Foreign Direct Investment Inflows of the World (FDIW) (CurrentUS\$) are taken from the World Development Indicators on the World Bank, Organized Industrial Zone (number by year) (OIZ )is taken from Organized Industrial Zone Supervisor. Technology Development Zone (Number by year) (TDZ) is taken from the Ministry of Industry and Technology. Free Zone (Number by year) (FZ) is taken from the Ministry of Industry and Technology. The total number of these zones (OIZ, TDZ, FZ) by year was calculated by the authors based on the years of establishment. Total Special Economic Zones (number by year) (SEZ) was calculated by calculating the sum of the OIZ, FZ and TDZ numbers.

\section{Models}

As seen in Figure 4, there is a high correlation between FDI inflows in Turkey and FDI inflows in the World. For this reason, we added to the model's World FDI inflows with the thought that FDI inflows in the world affect the FDI inflows in Turkey. One of the important policy tools for the development of countries is SEZs. It has been repeated in many studies in the literature that SEZs encourage FDI inflows. (Özocaklı,2021; Dorożyński et al.,2016; Chang, 2007; Tien et al.,2020; Peng,2020; Kaur\&Singh,2020). There has been a \$209 billion FDI inflow in Turkey, especially since the early 2000s. In addition, it is seen in Figure 6 that SEZs, which are thought to be determinative in the entry of foreign capital into the country, were more established in this period. Therefore we also included the number of total SEZs and the number of 
individual SEZ types in our model. With this thought, FDIT has measured a linear function according to the following equation:

FDIT $_{t}$

$=\mathrm{f}\left(\mathrm{FDIW}_{\mathrm{t}}, \mathrm{SEZ}_{\mathrm{t}}, \mathrm{OIZ}_{\mathrm{t}}, \mathrm{TDZ}_{\mathrm{t}}, \mathrm{FZ}_{\mathrm{t}}\right)$

To find the long term relationship between FDI inflows of Turkey, FDI inflows of the World, the number of Total SEZ, the number of the OIZ, the number of the TDZ, the number of FZare proposed the following log-linear form:

Model 1

$\operatorname{LnFDIT}_{\mathrm{t}}=$

$\alpha_{0}+\alpha_{1} \operatorname{LnFDIW}_{\mathrm{t}}+\alpha_{2} \operatorname{LnSEZ}_{\mathrm{t}}+$

$\mu_{\mathrm{t}}$

Model 2

$\operatorname{LnFDIT}_{\mathrm{t}}=$

$\beta_{0}+\beta_{1}$ LnFDIW $_{\mathrm{t}}+\beta_{2} \mathrm{LnOIZ}_{\mathrm{t}}+$

$\delta_{\mathrm{t}}$

Model 3

$\operatorname{LnFDIT}_{\mathrm{t}}=$

$\Upsilon_{0}+\Upsilon_{1} \operatorname{LnFDIW}_{\mathrm{t}}+\Upsilon_{2} \operatorname{LnTDZ}_{\mathrm{t}}+$

$\varphi_{\mathrm{t}}$

Model 4

$\operatorname{LnFDIT}_{\mathrm{t}}=$

$\sigma_{0}+\sigma_{1} \operatorname{LnFDIW}_{\mathrm{t}}+\sigma_{2} \mathrm{LnFZ}_{\mathrm{t}}+$

$\varepsilon_{\mathrm{t}}$

All the variables were transformed to natural logarithms for the analysis. We have used Eviews 10 to conduct the analysis.

\section{Methodology}

\section{Unit Root Test}

First, the Augmented Dickey-Fuller (ADF) tests are used to check whether each data series are integrated and has a unit root. The ADF test is based on the value of t-statistics for the coefficient of the lagged dependent variable compared with special calculated critical values. If the calculated value is greater than the critical value, then we reject the null hypothesis of a unit root; the unit root does not exist and our variable is stationary (Dickey and Fuller, 1979). 


\section{ARDL Test}

The Autoregressive Distributed Lag (ARDL) approach suggested by Pesaran et al (Granger, 1978) is applicable for variables that are I (0) or I (1) or fractionally integrated. The ARDL framework of Equation 6, 7, 8, 9 of the models is as follows:

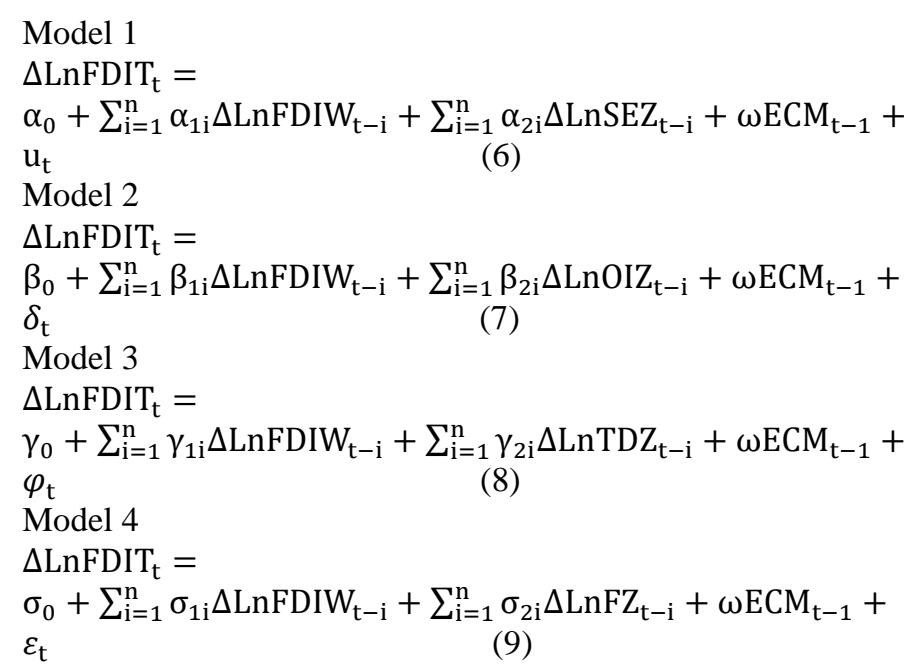

$\alpha_{0}, \alpha_{1}, \beta_{0}, \beta_{1}, \gamma_{0}, \gamma_{1}, \sigma_{0}, \sigma_{1}$ correspond to the long term relationship in models. Where $\mathrm{ECM}_{\mathrm{t}-1}$ is the error correction term which is gained from the following estimated cointegration equation?

Model 1

$\mathrm{ECM}_{\mathrm{t}}=$

$\operatorname{LnFDIT}_{\mathrm{t}}-\alpha_{0}+\sum_{\mathrm{i}=1}^{\mathrm{n}} \alpha_{1 \mathrm{i}} \Delta \operatorname{LnFDIW}_{\mathrm{t}-\mathrm{i}}+$

$\sum_{\mathrm{i}=1}^{\mathrm{n}} \alpha_{2 \mathrm{i}} \Delta \operatorname{LnSEZ}_{\mathrm{t}-\mathrm{i}}$

Model 2

$\mathrm{ECM}_{\mathrm{t}}=$

$\operatorname{LnFDIT}_{\mathrm{t}}-\beta_{0}+\sum_{\mathrm{i}=1}^{\mathrm{n}} \beta_{1 \mathrm{i}} \Delta \operatorname{LnFDIW}_{\mathrm{t}-\mathrm{i}}+$

$\sum_{\mathrm{i}=1}^{\mathrm{n}} \beta_{2 \mathrm{i}} \Delta \mathrm{LnOIZ}_{\mathrm{t}-\mathrm{i}}$

Model 3

$\mathrm{ECM}_{\mathrm{t}}=$

$\operatorname{LnFDIT}_{\mathrm{t}}-\gamma_{0}+\sum_{\mathrm{i}=1}^{\mathrm{n}} \gamma_{1 \mathrm{i}} \Delta \operatorname{LnFDIW}_{\mathrm{t}-\mathrm{i}}+$

$\sum_{\mathrm{i}=1}^{\mathrm{n}} \gamma_{2 \mathrm{i}} \Delta \mathrm{LnTDZ}_{\mathrm{t}-\mathrm{i}}$

Model 4

$\mathrm{ECM}_{\mathrm{t}}=$

$\operatorname{LnFDIT}_{\mathrm{t}}-\sigma_{0}+\sum_{\mathrm{i}=1}^{\mathrm{n}} \sigma_{1 \mathrm{i}} \Delta \operatorname{LnFDIW}_{\mathrm{t}-\mathrm{i}}+$

$\sum_{\mathrm{i}=1}^{\mathrm{n}} \sigma_{2 \mathrm{i}} \Delta \mathrm{LnFZ}_{\mathrm{t}-\mathrm{i}}$ 


\section{Empirical Analysis and Results}

The unit root test should be performed and the stationary variables should be evaluated to prevent spurious regression before models are estimated. The unit root test was performed using the generalized Dickey-Fuller (ADF) method and the results were given in Table 3 . As it is clear, all variables were not stationary. After taking the first difference of the variables, the variables are stationary.

Table 3. Augmented Dickey-Fuller Stationary Test Results

\begin{tabular}{|c|c|c|c|c|c|c|c|}
\hline \multirow{2}{*}{ Variable } & \multicolumn{3}{|c|}{ LEVEL (0) } & \multirow{2}{*}{ Variable } & \multicolumn{3}{|c|}{ LEVEL (1) } \\
\hline & $\begin{array}{l}\text { Critical } \\
\text { Value }\end{array}$ & t-Statistics & Prob & & $\begin{array}{l}\text { Critical } \\
\text { Value }\end{array}$ & t-Statistics & Prob \\
\hline LnFDIT & $\begin{array}{l}- \\
2.92255 \\
9\end{array}$ & -1.051735 & $\begin{array}{l}0.727 \\
3\end{array}$ & DLnFDIT & $\begin{array}{l}- \\
2.92378 \\
0\end{array}$ & $\begin{array}{l}- \\
10.00063 * \\
*\end{array}$ & $\begin{array}{l}0.000 \\
0\end{array}$ \\
\hline $\begin{array}{l}\text { LnFDI } \\
\text { W }\end{array}$ & $\begin{array}{l}- \\
2.92244 \\
9\end{array}$ & -1.560439 & $\begin{array}{l}0.494 \\
9\end{array}$ & $\begin{array}{l}\text { DLnFDI } \\
\mathrm{W}\end{array}$ & $\begin{array}{l}- \\
2.92378 \\
0\end{array}$ & $\begin{array}{l}- \\
5.676074 * \\
*\end{array}$ & $\begin{array}{l}0.000 \\
0\end{array}$ \\
\hline LnOIZ & $\begin{array}{l}- \\
2.92973 \\
4\end{array}$ & -2.605279 & $\begin{array}{l}0.099 \\
6\end{array}$ & DLnOIZ & $\begin{array}{l}- \\
2.72814 \\
2\end{array}$ & $\begin{array}{l}- \\
2.832386 * \\
*\end{array}$ & $\begin{array}{l}0.051 \\
8\end{array}$ \\
\hline LnTDZ & $\begin{array}{l}- \\
3.08100 \\
2\end{array}$ & $-4.460059 * *$ & $\begin{array}{l}0.002 \\
9\end{array}$ & & & & \\
\hline LnSEZ & $\begin{array}{l}- \\
2.92814 \\
2\end{array}$ & $\begin{array}{l}- \\
3.366362 * * \\
*\end{array}$ & $\begin{array}{l}0.017 \\
6\end{array}$ & & & & \\
\hline
\end{tabular}

Note: $(* *)$ and $(* * *)$ indicate $5 \%$ and $1 \%$ significance level respectively

Source: Authors Calculation using Eviews 10

Considering that the variables used in this research are stationary at different levels ((i (0), i (1)), the boundary test method is used to investigate the long term relationship between the variables of the above-proposed models. The ARDL Bound Test for each of the proposed model results was given in Table 4. If the computational F statistic is greater than the critical value of the upper bound, the null hypothesis that there is no long term relationship can be rejected regardless of the sum of variables. 
The Relationship between Foreign Direct Investment ...

Table 4. The Critical Values of Bound Test

\begin{tabular}{|c|c|c|c|}
\hline \multirow{2}{*}{ MODELS } & \multirow{2}{*}{ Computed F- a statistic } & \multicolumn{2}{|c|}{$\begin{array}{c}\text { Critical values } \\
\text { 5\% significant level }\end{array}$} \\
\cline { 3 - 4 } & & Lower bound I(0) & Upper bound I(1) \\
\hline Model 1 & $5.926417 * *$ & 3.79 & 4.85 \\
\hline Model 2 & $5.275091 * *$ & 3.79 & 4.85 \\
\hline Model 3 & $8.951487 * *$ & 4.87 & 5.85 \\
\hline Model 4 & $5.552011 * *$ & 3.79 & 4.85 \\
\hline
\end{tabular}

Note: $(* *)$ and $(* * *)$ indicate $5 \%$ and $1 \%$ significance level respectively

Source: Authors Calculation using Eviews 10

Conversely, if the F statistic is lower than the critical value of the lower bound, the null hypothesis cannot be rejected, and if the F statistic is placed between the upper and lower bounds, the test result is uncertain. It is shown that the obtained F statistics are larger than the upper limit at the level of 5\%, so the existence of the long term relationship between the model variables is confirmed. The results of the bound test indicate the existence of the long term relationship between the variables of all models. The long term and short term relationships between the variables examine using ARDL Test for the proposed models. Accordingly, the results of the ARDL Test are given in Table 5 and Table 6.

The results show that FDI inflows have a positive and significant effect on FDI inflows Turkey in the long term and the short term. Also, the number of Total SEZ has a positive and significant on the FDI inflows of Turkey. Namely, FDI inflows of Turkeyincrease $1.01 \%$ and $2.58 \%$ in the long term and short term respectively when the increase is $1 \%$ in the number of Total SEZ. While this effect is greater in the short term, it is seen that this effect decrease in the long term. The results of this study also show when the increase is $1 \%$ in the number of Organized Industrial Zone, while FDI inflows of Turkey increase $1.1 \%$ in the long term, FDI inflows of Turkey decrease $4.9 \%$ in the short term. When the increase is $1 \%$ in the number of Technology Development Zone, FDI inflows of Turkey increase $0.22 \%$ in the long term, while there is a positive and significant in the long term but it is insignificant in the short term. When the increase is $1 \%$ in the number of Free Zone, FDI inflows of Turkey increase $2.8 \%$ in the long term, while there is a positive and significant in the long term but it is insignificant in the short term. 
Iranian Journal of Finance, 2022, Vol. 6, No. 2 (Ozocakli, D.)

Table 5. Long Term Estimation Results

\begin{tabular}{|c|c|c|c|c|c|c|}
\hline \multicolumn{7}{|c|}{ Dependent Variable: LnFDIT } \\
\hline Models & Method & Variable & Coefficient & Std. Error & T-Statistic & Prob \\
\hline \multirow{2}{*}{ Models } & ARDL & LnFDIW & $1^{* * *}$ & 0.255551 & 4.638586 & 0.0001 \\
\cline { 3 - 7 } & $(1,4,0)$ & Ln SEZ & $1.01^{* * *}$ & 0.282668 & 4.638586 & 0.0001 \\
\hline \multirow{2}{*}{ Models 2 } & \multirow{2}{*}{$\begin{array}{c}\text { ARDL } \\
\end{array}$} & LnFDIW & $1.1^{* * *}$ & 0.319273 & 3.608626 & 0.0010 \\
\cline { 3 - 7 } & $(1,4,0)$ & LnOIZ & $1.1^{* * *}$ & 0.355736 & 3.093537 & 0.0041 \\
\hline \multirow{2}{*}{ Models 3 } & ARDL & LnFDIW & $1.6^{* * *}$ & 0.459350 & 3.112666 & 0.0046 \\
\cline { 3 - 7 } & $(1,0,0)$ & Ln TDZ & $0.22^{* * *}$ & 0.060281 & 3.687732 & 0.0024 \\
\hline \multirow{2}{*}{ Models 4 } & ARDL & LnFDIW & $4.7^{* * *}$ & 0.153589 & 30.878026 & 0.0000 \\
\cline { 3 - 7 } & $(1,1,0)$ & LnFZ & $2.8^{* * *}$ & 0.292876 & 9.566233 & 0.0000 \\
\hline
\end{tabular}

Note: $(* *)$ and $(* * *)$ indicate $5 \%$ and $1 \%$ significance level respectively

Source: Authors Calculation using Eviews 10

The main reason for the popularity of error correction patterns (ECMs) is that short term fluctuations of variables are related to their long term equilibrium values. If the error correction factor is with a negative sign, it indicates the speed of error correction and the desire for long term equilibrium. This coefficient shows what percentage of the imbalance of the dependent variable is adjusted in each period and approaches the long term relationship. Therefore the error correction factor in this estimation of all the models in this study is negative and it is interpretable as the percentage of the imbalance of the dependent variable is adjusted in each period are $0.49 \%, 0.49 \%, 0.80 \%$ and $0.80 \%$ for Model 1,2,3 and 4, respectively. As it is known, the highest rate of adjustment from short term to long term is related to Model 3 and 4, which include the FDI inflows of World, Free Zone and Technology Development Zone.

Table 6. Error Correction Model (ECM) for Short Term Elasticity

\begin{tabular}{|c|c|c|c|c|c|c|c|}
\hline Models & Method & Variable & Coefficient & Std. Error & T-Statistic & Prob & DW \\
\hline \multirow{3}{*}{$\begin{array}{c}\text { Models } \\
1\end{array}$} & \multirow{3}{*}{$\begin{array}{l}\text { ARDL } \\
(1,4,0)\end{array}$} & LnFDIW & $2.58 * * *$ & 0.158335 & 3.566909 & 0.0012 & \multirow{3}{*}{1.79} \\
\hline & & LnSEZ & $2.58 * *$ & 1.357777 & 1.890468 & 0.0677 & \\
\hline & & $\begin{array}{c}\text { ECM } \\
(-1)\end{array}$ & $-0.490192 * * *$ & 0.139536 & -3.513010 & 0.0013 & \\
\hline \multirow{3}{*}{$\begin{array}{c}\text { Models } \\
2\end{array}$} & \multirow{3}{*}{$\begin{array}{l}\text { ARDL } \\
(1,4,0)\end{array}$} & LnFDIW & $5.07 * * *$ & 0.136507 & 37.186300 & 0.0002 & \multirow{3}{*}{1.85} \\
\hline & & LnOIZ & $-4.9 * * *$ & 1.120715 & -4.431548 & 0.0001 & \\
\hline & & $\begin{array}{c}\text { ECM } \\
(-1)\end{array}$ & $-0.491880 * * *$ & 0.144918 & -3.382539 & 0.0019 & \\
\hline \multirow{3}{*}{$\begin{array}{c}\text { Models } \\
3\end{array}$} & \multirow{3}{*}{$\begin{array}{l}\text { ARDL } \\
(1,0,0)\end{array}$} & LnFDIW & $1.31 * * *$ & 0.413506 & 3.168274 & 0.0068 & \multirow{3}{*}{2.07} \\
\hline & & LnTDZ & 0.17 & 0.2143506 & 0.836963 & 0.4167 & \\
\hline & & $\begin{array}{c}\text { ECM } \\
(-1)\end{array}$ & $-0.806827 * * *$ & 0.163111 & -4.946843 & 0.0002 & \\
\hline
\end{tabular}


The Relationship between Foreign Direct Investment ...

\begin{tabular}{|c|c|c|c|c|c|c|c|}
\hline \multirow{3}{*}{$\begin{array}{c}\text { Models } \\
4\end{array}$} & ARDL & LnFDIW & $14.5 * * *$ & 0.153589 & 94.526947 & 0.0000 & \\
\cline { 3 - 7 } & $(1,1,0)$ & LnFZ & 0.17 & 0.292876 & 0.612405 & 0.5450 & \multirow{2}{*}{2.1} \\
\cline { 3 - 6 } & & $-0.806872^{* * * *}$ & 0.068612 & -11.759314 & 0.0000 & \\
\hline
\end{tabular}

Note: $(* *)$ and $(* * *)$ indicate $5 \%$ and $1 \%$ significance level respectively

Source: Authors Calculation using Eviews 10

Table 7. The Stability of the Models Coefficients

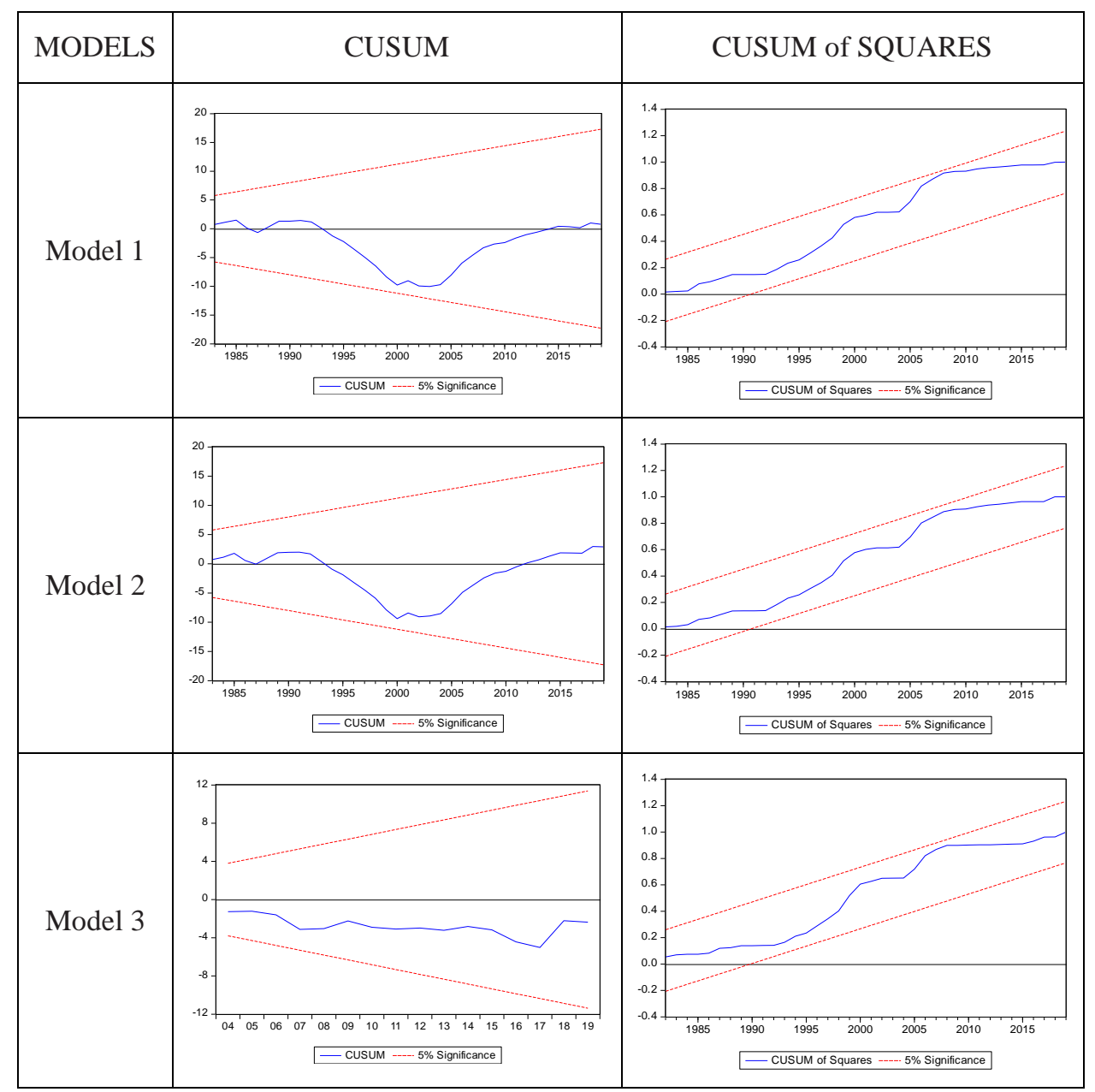




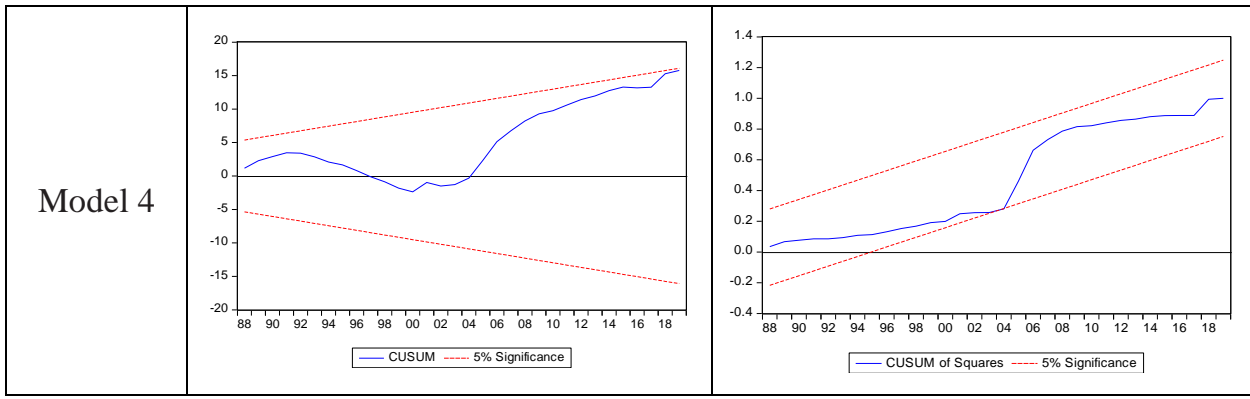

Note: (**)indicates 5\%

Source: Author's Estimation using Eviews 10

To evaluate the stability of the model coefficients, the Cumulative Sum of Recursive Residuals (CUSUM) Test, Cumulative Sum of Squares of Recursive Residuals (CUSUMQ) Test were used. In these tests, the null hypothesis means the stability of the parameters is at a significance level of 5\%. Table (7) shows the results of this test for the models studied in this research. According to the results, these graphs show that the statistics of this test are inside straight lines, which means that the coefficients are stable at a significance level of 5\%. In other words, the null hypothesis that the coefficients are stable at the $95 \%$ confidence level could not be refuted. In other words, the diagram in Table 7 shows that the estimated models at the level of $5 \%$ have structural stability and no failure is observed.

Finally, the models studied in this study were tested using diagnostic tests including White, Bruch-Goodfrey and Jarque-Bera Tests and the results are shown in Table 8 . The results indicate the absence of the problem of variance heterogeneity, autocorrelation and normal distribution of disorders, respectively.

Table 8. Diagnostic Tests

\begin{tabular}{|c|c|c|c|}
\hline MODELS & Test & F-Statistic & Prob \\
\hline Models 1 & \multirow{4}{*}{ White } & 1.189227 & 0.3367 \\
\hline Models 2 & & 0.793058 & 0.5986 \\
\hline Models 3 & & 1.16525 & 0.3521 \\
\hline Models 4 & & 1.378281 & 0.2659 \\
\hline Models 1 & \multirow{4}{*}{ Breusch-Godfrey } & 0.235232 & 0.7918 \\
\hline Models 2 & & 0.032052 & 0.9685 \\
\hline Models 3 & & 0.611789 & 0.5585 \\
\hline Models 4 & & 0.171443 & 0.8434 \\
\hline Models 1 & \multirow{4}{*}{ Jarque-Bera } & 1.095050 & 0.578380 \\
\hline Models 2 & & 1.879901 & 0.390647 \\
\hline Models 3 & & 0.266601 & 0.875202 \\
\hline Models 4 & & 1.389006 & 0.499323 \\
\hline
\end{tabular}

Source: Author's Estimation using Eviews 10 
The Relationship between Foreign Direct Investment ...

\section{Conclusion}

The United Nations stated that it has an important role for Foreign Direct Investment (FDI) in financing development and advancing towards sustainable development goals (UNCTAD, 2015: 213). Asiedu (2002) stated that countries need FDI flows to support domestic savings and that FDI flow not only provides the necessary capital for investment but also encourage growth and development by bringing employment, management skills and technology. The FDI contributes to the improvement of the workforce quality of the invested country, the increase of its welfare, and the more stable operation of its financial markets. At the same time, countries that can attract FDI are less affected by global economic fluctuations by reaching a wider pool of investors (Presidency of the Republic of Turkey Investment Office, 2020: 26).

SEZs are defined as regions with a limited geographic area, tax exemptions, flexible and private investment policies and practices in which procedures are simplified. SEZs are defined in the United Nations Conference on Trade and Development (UNCTAD) as the regions where production, trade and storage are not limited to time and are exempt from customs and taxes (FIAS, 10 2008). The number of SEZ has increased rapidly in Turkey since the 1980s. There are SEZs around the world that encourage FDI inflows and achieve remarkable results. Most SEZ established in the Asian Tigers in the 1970s and 1980s facilitated economic development by causing FDI inflows. Cumulative FDI inflows created by SEZs in China accounted for eighty percent of the total FDI inflows in the country, and SEZs have been found to have increased FDI inflows over the years. FDI, which inflowed the Ecozone region in the Philippines, was thirty percent in 1997 and reached 80 percent in 2000 (FIAS, 2008: 35). Inflowing the Export Processing Zones in Bangladesh, FDI inflows reached \$ 52 million in the period 1994-1999 and about \$1.5 billion in 2009 (Farole and Akinci, 2011: 29). The share of FDI inflows to SEZs in the Philippines increased from thirty percent in 1997 to over 80 percent in 2000 (UNCTAD, 2020).

This study it is analyzed the relationship between the FDI inflows of the World and the FDI inflows of Turkey and the type of the SEZ analyzed using the ARDL test from 1980 to 2019. The results show that FDI inflows of the World have a positive and significant effect on the FDI inflows of Turkey in the long term and the short term. Moreover, FDI inflows of the World have a positive and significant effect on the FDI inflows of Turkey in our all models. This effect maintains the robustness of this analysis. Considering the share of FDI inflows in the GDP, a slow increase was observed in the world towards the end of the 1980s, while a slow increase was observed in Turkey parallel to the world. In addition, while a great increase was observed in the world, especially towards the 2000s, a great increase was observed in Turkey in 2001 in parallel 
with the increase in the world. Namely, it is observed that Turkey moves in parallel with the world in terms of the share of FDI inflows in GDP. The results found are consistent with this parallel course of FDI inflows in the World and Turkey. Therefore, the increase in World FDI inflows will also positively affect Turkey. However, on the contrary, some global negative situations such as wars, pandemics and deterioration in the financial system will affect the World negatively and also may affect Turkey negatively. This is due to Turkey's fragile economic structure. Whereas countries that can attract FDI are less affected by global economic fluctuations by reaching a wider pool of investors (Presidency of the Republic of Turkey Investment Office, 2020: 26). To reduce this fragility and to be among these countries, it needs to increase its production volume by attracting more foreign capital. SEZs encourage foreign capital and foreign direct investment. Therefore SEZs should be used more effectively as the second-best policy tool. In other words, it is necessary to completely eliminate infrastructure (legal, commercial, industrial) problems by fully implementing the revisions and incentives (protection of foreign investor rights, compliance with international standards in investment and investor definitions, alleviation of bureaucracy, acceleration of processes, equal treatment with domestic investors, prevention of double taxation, bilateral investment protection agreements, employment, $R \& D$ and manufacturing tax reductions and exemptions) made since the beginning of the 2000s. And also the number of SEZs should be increased. Moreover, it is necessary to differentiate SEZ types according to country conditions and needs by thinking strategically.

Also, the number of Total SEZ has a positive and significant effect on the FDI inflows of Turkey. Namely, FDI inflows of Turkey increased $1.01 \%$ and $2.58 \%$ in the long term and short term respectively when the increase is $1 \%$ in the number of Total SEZ. While this effect is greater in the short term, it is seen that this effect decrease in the long term. Kaur and Singh (2020) stated that located 223 SEZs played an important key role in terms of FDI attracted to the Indian Economy from 2006 to 2018. Tien et al. (2020) determined that the causal relationship between the provincial FDI attracted and regional policies in the country were positive between 2011 and 2015. Wang (2013) stated that municipalities with more than one SEZ structure create greater impacts than municipalities with only one SEZ structure. According to the analysis results, it was found that SEZs caused an increase in FDI inflows in China. Chang (2007) stated that the adoption of the SEZ model in China under highly specific criteria provides a platform for FDI attraction. Liu and Peng (2020) determined that SEZs cause an increase in FDI inflows in China. Dorożyński et al. (2016) found that there is a statistically positive and significant relationship between SEZs and FDI inflows in Poland. It is seen that the increase in the number of 
SEZs in Turkey positively affects FDI inflows in the long term and short term and provides an important platform in terms of economic development. Therefore it seems that more attention should be given to SEZs as a policy tool. Increasing the SEZ numbers only is not enough. In addition, it is necessary to turn to SEZ types with new perspectives that are suitable for needs, compatible with emerging trends, high technology-oriented, export-oriented, and more strategically positioned. Moreover, logistics centers should be established beyond trade and labour-intensive production activities focusing on industries such as advanced technology, financial services and tourism.

Moreover in this study, the type of SEZ such as OIZ, TDZ, FZ has been analyzed. When the increase is $1 \%$ in the number of Organized Industrial Zone, while FDI inflows of Turkey increase $1.1 \%$ in the long term, FDI inflows of Turkey decrease $4.9 \%$ in the short term. There has been a steady increase in the number of OIZs in the period under consideration. Besides, the FDI inflows of Turkey has caught an increasing trend in the long term. However, there have been frequent fluctuations in FDI inflows in the short term. Therefore, it seems normal that the short term impact is negative. When the increase is $1 \%$ in the number of Technology Development Zone, FDI inflows of Turkey increase $0.22 \%$ in the long term, while there is a positive and significant in the long term but it is insignificant in the short term. Moreover, when the increase is $1 \%$ in the number of Free Zone, FDI inflows of Turkey increase $2.8 \%$ in the long term, while there is a positive and significant in the long-term. The number of Technology Development Zone and the number of Free Zone did not increase much in the short term. But they have caught an increasing trend in the long term. Therefore obtained the result seems consistent. In the period under consideration, the number of SEZs in Turkey affects the FDI inflow in the long term, not in the short term. In the long term the number of SEZ types (OIZ, TDZ, FZ), the number of total SEZ and the FDI inflows of the World have a positive and significant effect on the FDI inflows of Turkey. The positive and significant effect of both the number of total SEZ and the number of all SEZ types separately on FDI inflows of Turkey shows the robustness of the results obtained. For existing SEZ types, policymakers should implement SEZ policies taking into account the long term impact. Apart from this, policy measures should be taken to increase the effectiveness of existing SEZ types in the short term. In addition, different types of SEZs (such as logistics centers) applied in the world can increase the size of the impact, while the impact on FDI inflows can occur in a shorter period.

\section{Declaration of Conflicting Interests}

The authors declared no potential conflicts of interest concerning the research, authorship and, or publication of this article. 


\section{Funding}

The authors received no financial support for the research, authorship and, or publication of this article.

\section{References}

Aggarwal, A.,(2010). Economic impacts of SEZs: theoretical approaches and analysis of newlynotifiedSEZs in India. Department of Business Economics, University of Delhi, India. Unpublished.

Asiedu, E.,(2002). On the determinants of foreign direct investment to developing countries: Is Africa different? World Development, 30(1):107-119.

Chang, H.,(2007). Badsamaritans: Themyth of freetradeandthesecrethistory of capitalism. Bloomsbury Publishing USA.

Çakmak, E., Önden, İ.,Samastı, M.,(2017). Türkiye'deki ve dünya'daki özel bölgeler ve özel ekonomi bölgesi oluşturulması için dönüşüm önerileri, 6. Ulusal Lojistik ve Tedarik Zinciri Kongresi.

Dickey, D., Fuller, W., (1979). "Distribution of the Estimates for Autoregressive Time Series with a Unit Root". Journal of the American Statistical Association. Vol. 74, pp. 427-4311. Available:http://dx.doi.org/10.2307/2286348.

FIAS, (2008). Special economic zones performance lessons learned and implications for zone development, April, The Multi-DonorInvestmentClimateAdvisory Service of the World Bank.Foreign Direct Investment Law, No:4875, Number:25141, Vol:42.,

Granger, C., W.J., R.F. Engle,.(1987).Cointegration and error correction: representation, estimation and testing. Econometrica.

Kaur, J, Singh, K.,(2020). Impact of specialeconomiczones on the Indian economy. Journal of EconomicsandTrade, 5(1):25-28. Retrievedfromhttps://www.ikprress.org/index.php/JET/article/view/5099.

OrganizedIndustrialZonesLaw,. (2000) No:4562, Number:24021, Vol:39.

Presidency of theRepublic of TurkeyInvestment Office,. (2020). Türkiye'de Uluslararas1 Doğrudan Yatırımlar.p.26-31.

Presidency of theRepublic of TurkeyInvestment Office, (2021a) Whyİnvest in Turkey? p.13-21

Presidency of theRepublic of TurkeyInvestment Office,. (2021b). Sektörler, Enerji, https://www.invest.gov.tr/tr/sectors/sayfalar/energy.aspx, $\quad$ Erişim Tarihi:1.5.2021.

The ministry of IndustryandTechnologyStatistical Data, (2021)https://www.sanayi.gov.tr/istatistikler/istatistiki-bilgiler/mi0203011501, Erişim Tarihi:27.1. 
Song,Y., Deng, R., Liu, R., Peng, Q.,(2020). Effects of special economic zones on fd1 in emerging economies: does institutional quality matter? Sustainability, 12(20):8409. https://doi.org/10.3390/su12208409.

The World Bank Data Catalog, Special EconomicZonehttps://datacatalog.worldbank.org/dataset/special-economiczones-sez.

Tien, DN., Huong, NQ.,(2020). Assessment of industrial cluster policies in Vietnam: the role of special economic zones in attracting foreign direct investment. (C) EconomicResearchInstitutefor for ASEAN and East Asia. http://hdl.handle.net/11540/12202.

UNCTAD(2015). World Investment Report 2015.

UNCTAD(2019).World Investment Report 2019.

UNCTAD(2020). World Investment Report 2020.

UNCTAD ( 2019). World Development Report, Special economic zones.

UNDP(2015).Comparative study on special economic zones in Africa and China. WorkingPaper Series, No.6.

Wang, J.,(2013).The economic impact of special economic zones: evidence from Chinese municipalities. Journal of Development Economics, 101:133-147.

Zou, X.,(2018). VECM model analysis of carbon emissions, GDP and international crude oil prices. Discrete Dynamics in Nature and Society, 2018(2):1-11.

\section{Bibliographic information of this paper for citing:}

Ozocakli, Demet \& Khanalizadeh, Bahman (2022). The Relationship between Foreign Direct Investment Inflows of World, Foreign Direct Investment Inflows of Turkey and Types of the Special Economic Zone: Evidence from 1980-2019. Iranian Journal of Finance, 6(2), 1-27.

Copyright @ 2022, Demet Ozocakli and Bahman Khanalizadeh

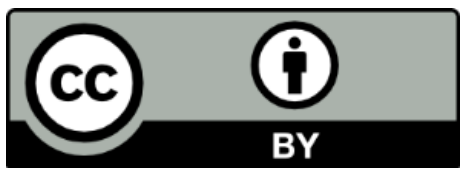

